Elżbieta Wszelaczyńska*, Jarosław Pobereżny*, Katarzyna Gościnna*, Jarosław Chmielewski*, Tomasz Knapowski* ${ }^{* *}$, Wojciech Kozera***, Edward Majcherczak ${ }^{* * *}$

\title{
Environmental and technological carrot safety conditions Part I. Changes in the content of nitrates determined by the environment and processing
}

\section{Środowiskowe i technologiczne uwarunkowania jakości marchwi. Część I. Zmiany zawartości azotanów determinowane jakością środowiska i procesami przetwarzania}

\begin{abstract}
* Dr inż. Elżbieta Wszelaczyńska, dr inż. Jarosław Pobereżny, dr inż. Katarzyna Gościnna - Department of Food Technology, Faculty of Agriculture and Biotechnology, UTP University of Science and Technology in Bydgoszcz, Kordeckiego 20A St., 85-225 Bydgoszcz, Poland, e-mail: wszela@utp.edu.pl ** Dr Jarosław Chmielewski - Institute of Environmental ProtectionNational Research Institute, Krucza 5/11d St., 00-548 Warsaw
\end{abstract}

*** Dr inż. Tomasz Knapowski, dr inż. Wojciech Kozera, dr inż. Edward Majcherczak - Department of Agricultural Chemistry, Faculty of Agriculture and Biotechnology, UTP University of Science and Technology in Bydgoszcz, Kordeckiego 20A St., 85-225 Bydgoszcz, Poland

Keywords: environment, nitrates, ADI, magnesium, processing, intake

Słowa kluczowe: środowisko, azotany, ADI, magnez, marchew, przetwórstwo, spożycie

\begin{abstract}
The aim of the research was to define changes in the content of $\mathrm{NO}^{-}$determined by the environment and processing in products from five cultivars of carrot, orange in colour. Besides this, in the research, the human intake of toxic compounds found in processed foods was also assayed. All the processed foods were produced at laboratory scale compliant with the applicable guidelines and norms. The content of nitrates in processed foods depended significantly on the genetic conditions of material and on the processing method. Of all the cultivars under study, 'Karotan' was least applicable to processing since, irrespective of the processing method, the lowest decrease in nitrates was reported for that cultivar. The consumption of processed foods from the cultivars of carrot studied is not hazardous to consumer health, since the value of the ADI in adult, Acceptable Daily Intake, is not exceeded.
\end{abstract}

(C) IOŚ-PIB

\section{INTRODUCTION}

The occurrence of some amounts of nitrates and other harmful compounds is normal as it is a consequence of natural nitrogen cycling in nature [Niewczas et al. 2006, Malinowska et al. 2007]. Simplifications in root vegetable crops growing by eliminating some practices can enhance the environmental conditions for plant growth and development [Wszelaczyńska et al. 2014]. Nitrates accumulation in plants results from physiological process of nitrogen nutrition in plants in the form of $\mathrm{N}^{-\mathrm{NO}_{3}}$, taken up by plants at definitely higher amounts than $\mathrm{N}^{-\mathrm{NH}_{4}}$. With that in mind, it is important to determine the condition of natural environment pollution, especially the content of harmful compounds in plants for consumption grown in the regions exposed, today or in the future, to intensive human impact [Szwalec, Mundała 2012].

\section{Streszczenie}

Celem przeprowadzonych badań było określenie zmian zawartości $\mathrm{NO}^{-}$determinowanych środowiskiem i procesami przetwarzania w produktach wytworzonych z marchwi pięciu pomarańczowych odmian. Ponadto określono wielkość spożycia przez człowieka związków toksycznych znajdujących się w przetworach. Wszystkie przetwory zostały wyprodukowane w skali laboratoryjnej zgodnie z zaleceniami i normami. Zawartość azotanów w przetworach zależała istotnie od uwarunkowań genetycznych surowca oraz sposobu przetworzenia. $Z$ badanych odmian najmniej do przetwórstwa nadawała się odmiana 'Karotan', gdyż niezależnie od metody przetwarzania dla tej odmiany uzyskano najmniejszy spadek azotanów. Spożycie przetworów uzyskanych $\mathrm{z}$ badanych odmian marchwi nie zagraża zdrowiu konsumentów, gdyż nie zostaje przekroczona wyznaczona norma ADI czyli dziennego dopuszczalnego spożycia przez dorosłego człowieka.

Nitrates are one of the substances most unwanted both in plant material and in its processed foods. The 70 to $90 \%$ share of nitrates in daily human rations comes from vegetables [Tamme et al. 2006, Bottex et al. 2008, Gajewska et al. 2009, Gajewski et al. 2010, lerna 2009, Łozowicka 2009, Ciećko et al. 2010]. In the group of vegetables, carrot (Daucus carota L.) has a considerable share in human nutrition since its annual consumption is $20.0 \mathrm{~kg}$ per person, of which $8 \mathrm{~kg}$ as raw vegetable. Carrot is a plant with a high tendency to $\mathrm{NO}^{-}$accumulation; for this reason, monitoring its content in fresh carrot and its processed foods should be a norm [Grudzińska, Zgórska 2005, Czerwińska \& Zgórska 2011]. According to the norms, the content of nitrates (V) in carrot should not exceed $400 \mathrm{mg} \cdot \mathrm{kg}^{-1}$ in fresh weight, and 
in the case of carrot allocated to processed foods for children below 3 years of age, only $200 \mathrm{mg} \cdot \mathrm{kg}^{-1}$ in fresh weight [Gajewski et al. 2010, Grudzińska, Zgórska 2005, Murawa et al. 2008, Wrzodak, Elkner 2010]. Processed foods are the key section of food industry. Their availability on the market throughout the year facilitates satisfying high consumer needs. Processed foods, to be sold in the market, must satisfy specific quality, sensory and microbiological requirements [Pobereżny, Wszelaczyńska 2013]. About $20 \%$ of the total carrot harvest is allocated to processing [Nawirska, Król 2004, Gębczyński 2006, Domaradzki et al. 2010]. Carrot processing mostly covers the following technologies: freezing, preserving, drying, processed foods for children and drinking juices. Also, in household conditions, carrot is exposed to processing, for example, by conserving, freezing, and so on [Jąder \& Wawrzyniak 2015]. The most common method is vegetable freezing. It is considered a preservation method which is little invasive; produce differs in its content of nutrients from raw products only slightly [Zalewska - Korona et al. 2015]. To limit the content of unwanted components and prolong the processed food applicability, new solutions or improvements of the existing preservation and storage methods are explored [Kobus et al. 2014]. The quality of processed foods also depends on the adequately performed technological process [Kowalska 2006]. The aim of the present research was to determine changes in the content of $\mathrm{NO}^{-}$determined by the environment and processing in the products of five carrot cultivars, orange in colour, as well as the human intake of toxic compounds found in processed foods.

\section{MATERIAL AND RESEARCH METHODS}

The research material was derived from 3-year field experiments carried out at Mochełek (the kujawsko - pomorskie province). The research involved five cultivars of orange carrot ('Berjo', 'Flacoro', 'Karotan', 'Koral' and 'Perfekcja') grown compliant with the requirements of agrotechnical practises, with a constant fertilisation rate of nitrogen $-70 \mathrm{~kg} \mathrm{~N} \cdot \mathrm{ha}^{-1}$, phosphorus $-80 \mathrm{~kg}$ $\mathrm{P}_{2} \mathrm{O}_{5} \cdot \mathrm{ha}^{-1}$ and potassium $100 \mathrm{~kg} \mathrm{~K}_{2} \mathrm{O} \cdot \mathrm{ha}^{-1}$. An experiment factor was made up by biofortification with magnesium at the rate of 0 , 45 and $90 \mathrm{~kg} \mathrm{MgO} \cdot \mathrm{ha}^{-1}$ in the form of magnesium sulphate (16\%). Magnesium was applied as a foliar fertiliser in the form of $3 \%$ solution of magnesium sulphate over the period of an intensive plant growth.

In material and once it has been preserved, in processed foods, the content of nitrates $(\mathrm{V})$ was assayed with the ionoselective method with multifunctional computer device $\mathrm{CX}-721$ provided by Elmetron [Baker \& Thompson 1992]. Carrot allocated to preserved and frozen foods was cut into cubes $1 \times 1 \times 1 \cdot 10^{-2} \mathrm{~m}$, while carrot for drying was sliced into $4 \cdot 10^{-3} \mathrm{~m}$ pieces. The cut carrot was blanched at a temperature of $95^{\circ} \mathrm{C}$ for 3 minutes and cooled under running cold water. Freezing was performed in a box freezer (Whirlpool, CO405W, Electronic Control System) at the temperature from -22 to $-24^{\circ} \mathrm{C}$. Drying was done at $60^{\circ} \mathrm{C}$ in the laboratory drier (SUP - 100) with forced air circulation. The preserved carrot was prepared compliant with the norm (PN-A77807:1997/Az1:2004).
The paper has been an attempt at model-determination of daily intake of nitrates $(\mathrm{V})$ assuming the consumption of $55 \mathrm{~g}$ of processed carrot per person. The data was compared with the norms (JECFA 2002) considering the Acceptable Daily Intake (ADI).

The results of the 3-year research were exposed to statistical calculations with the analysis of variance for two-factor experiments, with the Tukey test to verify the significance of differences.

\section{RESULTS AND DISCUSSION}

The content of nitrates $(\mathrm{V})$ in frozen foods, preserved carrot and dried materials from the five cultivars are provided in (Tables 1 , 2 and 3). The research has shown differences in the content of nitrates $(\mathrm{V})$ between frozen foods, preserved foods and dried materials produced at laboratory scale from various cultivars. The lowest content of nitrates $(\mathrm{V})$ was contained in frozen foods from 'Perfekcja' and 'Karotan' and preserved foods and dried materials from 'Perfekcja' and 'Koral'. The highest content of nitrates $(V)$ was shown for all the processed foods from 'Flacoro' and 'Berjo'. Wojciechowska [2005], Bender et al. [2009] and Wrzodak \& Elkner [2010] have proven that the accumulation of nitrates $(V)$ in vegetables is not only plant specific - but also plant cultivar specific.

In the present research, irrespective of the cultivar, the content of nitrates $(V)$ in processed foods from carrot as a result of magnesium application was lower than in processed foods from carrot without magnesium (Table 1, 2, 3). The lowest content of nitrates $(V)$ was reported for processed foods from carrot after applying magnesium at the rate of $90 \mathrm{~kg}$. Only for preserved carrot, a significant decrease in the content of nitrates $(\mathrm{V})$ was recorded following $\mathrm{Mg}$ application at each rate: $45 \mathrm{~kg}$ and 90 $\mathrm{kg}$. The applicable literature shows that plant biofortification with magnesium enhances the plant health status by limiting the development of pathogenic bacteria, which, as a consequence, decreases the contents of nitrates $(V)$ in material. Apart from this, applying magnesium in a sulphate form increases the soil reaction and helps decreasing the accumulation of nitrates $(\mathrm{V})$ in plants. Additionally, magnesium increases its concentration in plants and intensifies photosynthesis, which can also decrease the content of nitrates (V) [Smoleń \& Sady 2007].

The results of changes in the content of nitrates $(V)$ due to processing are given in Table 1,2 and 3. The highest loss of nitrates (V) was caused by preserving; mean for cultivars $58 \%$ and the lowest - freezing $27 \%$. Drying decreased the content of nitrates $(\mathrm{V})$, mean for cultivars, by $40 \%$. A decrease in the content of nitrates $(\mathrm{V})$ in processed foods from carrot storage roots due to thermal treatment was noted by Grudzińska \& Zgórska [2005]. The authors in their research with varied carrot cultivars throughout processing recorded a decrease in the content of nitrates $(\mathrm{V})$ on an average, for all the cultivars from 11 to $30 \%$. The authors also note that material peeling increases the content of nitrates $(\mathrm{V})$ by $3 \%$ and claim that it must have been due to the highest amounts of nitrates (V) in carrot being found in inner spine and by peeling the total root weight decreases, thus increasing its ratio to the weight. 
Table 1. Changes in the content of nitrates $(\mathrm{V})$ in carrot exposed to freezing.

\begin{tabular}{|c|c|c|c|}
\hline $\begin{array}{c}\text { Cultivar } \\
\text { [I] }\end{array}$ & Content of nitrates $\mathbf{~ V ) ~} \mathbf{( m g} \cdot \mathbf{k g}^{-1}$ fresh weight) & $\begin{array}{c}\text { Change } \\
\text { in content (\%) }\end{array}$ \\
\hline Berjo & Fresh carrot & Frozen carrot & -29 \\
\hline Flacoro & 229.3 & 163.3 & -33 \\
\hline Karotan & 277.2 & 186.3 & -23 \\
\hline Koral & 236.0 & 182.4 & -24 \\
\hline Perfekcja & 245.4 & 187.2 & -27 \\
\hline Magnesium application* & 223.9 & 163.0 & $\begin{array}{c}\text { Change } \\
\text { in content (\%) }\end{array}$ \\
\hline 0 & Fresh carrot & Frozen carrot & -29 \\
\hline 45 & 235.8 & 166.5 & -29 \\
\hline
\end{tabular}

* Magnesium rate $\left[\mathrm{kg} \mathrm{MgO} \cdot \mathrm{ha}^{-1}\right]$

LSD at $\alpha=0.05$

I- $11.0 \quad \mathrm{II} / \mathrm{I}-\mathrm{n} . \mathrm{s}$.

II - 8.2 I/II-n.s.

Table 2. Changes in the content of nitrates $(\mathrm{V})$ in carrot preserved in jars.

\begin{tabular}{|c|c|c|c|}
\hline \multirow{2}{*}{$\begin{array}{l}\text { Cultivar } \\
\text { [l] }\end{array}$} & \multicolumn{2}{|c|}{ Content of nitrates(V) $\left(\mathrm{mg} \cdot \mathrm{kg}^{-1}\right.$ fresh weight) } & \multirow{2}{*}{$\begin{array}{c}\text { Change } \\
\text { in content (\%) }\end{array}$} \\
\hline & Fresh carrot & Carrot preserved in jars & \\
\hline Berjo & 229.3 & 96.8 & -58 \\
\hline Flacoro & 277.2 & 112.0 & -60 \\
\hline Karotan & 236.0 & 107.1 & -55 \\
\hline Koral & 245.4 & 99.6 & -59 \\
\hline Perfekcja & 223.9 & 87.8 & -61 \\
\hline $\begin{array}{c}\text { Magnesium application* } \\
\text { [II] }\end{array}$ & Fresh carrot & Carrot preserved in jars & $\begin{array}{c}\text { Change } \\
\text { in content }(\%)\end{array}$ \\
\hline 0 & 235.8 & 100.2 & -58 \\
\hline 45 & 242.9 & 97.4 & -60 \\
\hline 90 & 249.1 & 103.9 & -58 \\
\hline
\end{tabular}

* Magnesium rate $\left[\mathrm{kg} \mathrm{MgO} \cdot \mathrm{ha}^{-1}\right]$

LSD at $\alpha=0.05$

I- $16.7 \quad \mathrm{II} / \mathrm{I}-\mathrm{n} . \mathrm{s}$.

II - 6.6 I/II-n.s.

In the present research, the highest loss of nitrates $(\mathrm{V})$ was reported for frozen foods from 'Flacoro' and 'Berjo' (mean of $60 \%$ ), for preserved carrot from 'Perfekcja' and 'Flacoro' (mean of $31 \%)$ and for dried materials from 'Berjo' and 'Perfekcja' (mean of $60 \%$ ). All the preserved foods, on the other hand, from 'Karotan' showed the lowest loss of nitrates (V); $23 \%$ for frozen carrot, $55 \%$ for preserved carrot and $24 \%$ for dried material, respectively. As seen from Tables 1, 2 and 3, the material that was not biofortified with magnesium received the highest losses of nitrates $(\mathrm{V})$ in the process of carrot preserving and drying. The use of different environmental conditions (with and without the use of magnesium) significantly affected the nitrates content in the tested products processed from carrots. Applying magnesium showed unfavourable as it limited the losses of nitrates $(V)$ in dried and preserved carrot, as compared with losses in products from non-biofortified materials.

Opposite results were recorded for frozen carrot. Applying magnesium, irrespective of the amount, increased the losses of nitrates $(V)$ in frozen foods, as compared to frozen foods from carrot without biofortification. After freezing, a decrease in the content of nitrates (V) was noted for biofortified carrot with 45 $\mathrm{kg}$ of magnesium by $1 \%$ and with the rate of $90 \mathrm{~kg} \mathrm{MgO}-$ by $4 \%$. According to various sources, vegetable consumption should be about $500 \mathrm{~g}$ in 4-5 meals a day, including $55 \mathrm{~g}$ of carrot. An attempt was made at a model-determination of the daily intake of nitrates $(V)$ in processed foods from the cultivars under study (Table 4). The highest nitrates (V) intake is noted for consuming $55 \mathrm{~g}$ of frozen carrot and preserved carrot from 'Flacoro'; it is $10.2 \mathrm{mg}$ for frozen carrot and $6.2 \mathrm{mg}$ for preserved carrot. For the other cultivars, the intake is lower and it is, on an average, $9.6 \mathrm{mg}$ for frozen and $5.4 \mathrm{mg}$ for preserved carrot. Considering the Acceptable Daily Intake (ADI) by an adult, which equals $222 \mathrm{mg}$ of nitrates $(\mathrm{V})$, the consumption of frozen carrot and preserved carrot from the cultivars studied does not exceed the norm. Much higher amounts of nitrates $(\mathrm{V})$ are introduced with the consumption of dried material from those cultivars and most nitrates $(\mathrm{V})$ are introduced to the body with dried material from 'Karotan'. As for 'Karotan' dried material, we introduce $75.8 \mathrm{mg}$ 
Table 3. Changes in the content of nitrates (V) in carrot exposed to drying.

\begin{tabular}{|c|c|c|c|}
\hline \multirow{2}{*}{$\begin{array}{l}\text { Cultivar } \\
\text { [I] }\end{array}$} & \multicolumn{2}{|c|}{ Content of nitrates (V) ( $\mathrm{mg} \cdot \mathrm{kg}^{-1}$ fresh weight) } & \multirow{2}{*}{$\begin{array}{c}\text { Change } \\
\text { in content }(\%)\end{array}$} \\
\hline & Fresh carrot & Dried carrot & \\
\hline Berjo & 229.3 & 920 & -48 \\
\hline Flacoro & 277.2 & 1219 & -43 \\
\hline Karotan & 236.0 & 1379 & -24 \\
\hline Koral & 245.4 & 1194 & -37 \\
\hline Perfekcja & 223.9 & 922 & -47 \\
\hline $\begin{array}{l}\text { Magnesium application* } \\
{[\text { [I] }}\end{array}$ & Fresh carrot & Dried carrot & $\begin{array}{c}\text { Change } \\
\text { in content }(\%)\end{array}$ \\
\hline 0 & 235.8 & 1055 & -42 \\
\hline 45 & 242.9 & 1105 & -41 \\
\hline 90 & 249.1 & 1203 & -37 \\
\hline
\end{tabular}

* Magnesium rate $\left[\mathrm{kg} \mathrm{MgO} \cdot \mathrm{ha}^{-1}\right]$

LSD at $\alpha=0.05$

I-88.3 IIII-n.s.

II -48.6 I/II- n.s.

Table 4. Daily intake of nitrates (V) while consuming $55 \mathrm{~g}_{\text {of }}$ carrot $^{*}\left(\mathrm{mg} \cdot \mathrm{day}^{-1}\right)$.

\begin{tabular}{|c|c|c|c|c|}
\hline Cultivar & $\begin{array}{c}\text { Fresh carrot } \\
\text { (Right after harvest) }\end{array}$ & Frozen carrot & Carrot preserved in jars & Dried carrot \\
\hline Berjo & 12.6 & 9.0 & 5.3 & 50.6 \\
\hline Flacoro & 15.2 & 10.2 & 6.2 & 67.0 \\
\hline Karotan & 13.0 & 10.0 & 5.9 & 75.8 \\
\hline Koral & 13.5 & 10.3 & 5.5 & 65.7 \\
\hline Perfekcja & 12.3 & 9.0 & 4.8 & 50.7 \\
\hline Magnesium application** & & & & \\
\hline 0 & 13.0 & 9.2 & 5.5 & 58.0 \\
\hline 45 & 13.4 & 9.5 & 5.4 & 60.8 \\
\hline 90 & 13.7 & 10.2 & 5.7 & 66.1 \\
\hline MEAN & 13.3 & 9.6 & $\mathbf{5 . 5}$ & $\mathbf{6 1 . 7}$ \\
\hline
\end{tabular}

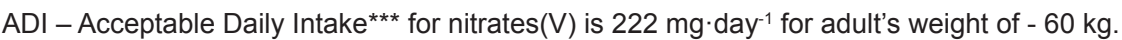

* - mean consumption of fresh and processed carrot (without juice) is $20 \mathrm{~kg} \cdot y e a r^{-1}$ per person in Poland.

** - Magnesium rate $\left[\mathrm{kg} \mathrm{MgO} \cdot \mathrm{ha}^{-1}\right]$

*** - The Joint FAO/WHO Expert Committee [JECFA 2002] for foodstuffs has determined the (ADI) daily intake of nitrates (V) by adult amounting to $0-3.7 \mathrm{mg}$ per $\mathrm{kg}$ of body weight [Burt et al. 1993]

per day to the body, which accounts for about $34 \%$ of ADI and as for the other cultivars - an average of $58.5 \mathrm{mg}$, which accounts for $26.4 \%$ of the ADI. Tamme et al. [2006], monitoring the Estonian market, defined the daily intake of nitrates $(\mathrm{V})$ introduced into the body with vegetables for adults as $58 \mathrm{mg} \mathrm{day}^{-1}$, for children at 4 to 6 years of age $-30 \mathrm{mg}$ and for new-born children $-7.8 \mathrm{mg}$. Similarly, as in the present research, they did not exceed the ADI norm.

\section{CONCLUSIONS}

Changes due to the use of modern cultivation technology (biofortification plants of magnesium with standard plant protection products) enhanced the environmental conditions for carrot growing in the vegetation period, which decreased the content of nitrates $(\mathrm{V})$, especially in frozen carrot. In that respect the application of magnesium at the amount of $90 \mathrm{~kg} \mathrm{MgO}$ was most beneficial. The content of nitrates (V) in processed foods depended significantly on genetic conditions of material and on the processing method. The processing technology and genetic conditions significantly affected the safety of the processed foods, and thus, the safety of consumers.

Of all the cultivars, 'Karotan' was least applicable to processing since, irrespective of the processing method, the lowest decrease in nitrates (V) was noted in 'Karotan'. The calculated mean daily intake of carrot in a processed form does not exceed the ADI norm. Due to the toxic effect of nitrate compounds, regular monitoring of content and the occurrence of those compounds, not only in material but also in processed foods, allowed in the market is necessary. 


\section{REFERENCES}

BAKER W. H., THOMPSON T. L. 1992. Determination of nitrate nitrogen in plant samples by selective ion electrode. Plant Anal. Ref. Proc. for S. US (SCSB \# 368): 23-26.

BENDER I., ESS M., MATT D., MOOR U., TÕNUTARE T., LUIK A. 2009. Quality of organic and conventional carrots. Agronomy Research 7 (Special issue II): 572-577,

BOTTEX B., LOU J., DORNE C.M., CARLANDER D, BEDFORD D., PRZYREMBEL H., HEPPNER C., KLEINER J., COCKBURN A. 2008. Risk - benefit health assessment of food Food fortification and nitrate in vegetables. Trends in Food Science \& Technology 19: 109-115

BURT T.P., HEATHWAITE A.L., TRUDGILL S.T. 1993. Nitrate: Process, pattern and management. Chichester, England, Wiley: 10-28.

CIEĆKO Z., ŻOŁNOWSKI A., MIERZEJEWSKA A. 2010. Effect of Foliar Nitrogen and Magnesium Fertilization on the Total, Protein Nitrogen and Nitrates(V) Content in Potato Tubers. Ecological Chemistry and Engineering 17: 593-600.

CZERWIŃSKA E., ZGÓRSKA K. 2011. Zmiany jakości minimalnie przetworzonej marchwi pakowanej próżniowo w czasie przechowywania. Rocznik Ochrona Środowiska T.13: 845-858

DOMARADZKI P., MALIK A., WÓJCIK W. 2010. Zawartość $\beta$-karotenu i witaminy $\mathrm{C}$ w wybranych produktach z marchwi. Bromatologia i Chemia Toksykologiczna XLII: 118-123.

GAJEWSKA M., Czajkowska A., Bartodziejska B. 2009. Zawartość azotanów (III) i (V) w wybranych warzywach dostępnych w handlu detalicznym regionu łódzkiego. Ochrona Środowiska i Zasobów Naturalnych 40: 388-395.

GAJEWSKI M., SZYMCZAK P., DANILCENKO H. 2010. Changes of physical and chemical traits of roots of different carrot cultivars under cold store conditions. Vegetable Crops Research Bulletin 72: 115-127

GĘBCZYŃSKI P. 2006. Content of selected antioxidative compounds in raw carrot and in frozen product prepared for consumption. Electronic Journal of Polish Agricultural Universities, ser. Food Sci. Technol., 9(3), Available Online: http://www.ejpau.media.pl/volume9/issue3/art-03.html

GRUDZIŃSKA M., ZGÓRSKA K. 2005. Effect of preliminary and thermal processing on the content of nitrate in vegetables. Rocznik Ochrona Środowiska T.7: 233-241

IERNA A. 2009. Influence of harvest date on nitrate contents of three potato varieties for off-season production. Journal of Food Composition and Analysis 22: 551-555.

JĄDER K., WAWRZYNIAK J. 2015. Zmiany w spożyciu owoców i warzyw oraz ich przetworów w Polsce w latach 1999-2013 a zjawisko zrównoważonej konsumpcji. Journal of Agribusiness and Rural Development 3: 427-435.

JECFA. 2002. Commission Regulation No. 563/2002 of 2 April 2002 amending Regulation (EC) No 466/2001 setting maximum levels for certain contaminants in foodstuffs. FAO/WHO Expert Committee on Food Additives (JECFA). Official Journal of the European Communities L86, 03/04/2002: 5-6.

KOBUS Z., BŁASZCZUK I., WILCZYŃSKI K. 2014. Wpływ procesów pasteryzacji i zamrażania na właściwości reologiczne soku z pietruszki. Acta Scientiarum Polonorum Technica Agraria $13: 23-30$.
KOWALSKA H. 2006. Nasycenie marchwi chlorkiem wapnia w czasie odwadniania osmotycznego. Inżynieria Rolnicza 3: 135142.

ŁOZOWICKA B. 2009. Chemiczne zanieczyszczenia żywności pochodzenia roślinnego. Progress in Plant Protection 49: 20712080.

MALINOWSKA E., GROMKOWSKA A., SZEFER P. 2007. Zawartość azotanów (V) i azotanów (III) w roślinach strączkowych. Bromatologia i Chemia Toksykologiczna XL: 287-291.

MURAWA D, BANASZKIEWICZ B., MAJEWSKA E., BŁASZCZUK B., SULIMA J. 2008. Nitrate and nitrite content in selected vegetables and potatoes commercially available in Olsztyn. Bromatologia i Chemia Toksykologiczna XLI: 67-71

NAWIRSKAA., KRÓLA. 2004. Marchew - porównanie wybranych składników chemicznych czterech odmian. Przemysł Fermentacyjny i Owocowo-Warzywny 1: 25-26.

NIEWCZAS J., KAMIONOWSKA M., MITEK M. 2006. Zawartość azotanów (III) i (V) w owocach nowych odmian dyni olbrzymiej (Cucurbita maxima). Żywność. Nauka. Technologia. Jakość 2: 238-245.

Norma PN-A-77807:1997/Az1:2004. Produkty warzywne. Warzywa konserwowe.

POBEREŻNY J., WSZELACZYŃSKA E. 2013. Wpływ metod konserwacji na wybrane cechy jakościowe owoców i warzyw znajdujących się w handlu detalicznym. Inżynieria i Aparatura Chemiczna 52: 92-94.

SMOLEŃ S., SADY W. 2007. Wpływ formy azotu i dokarmiania dolistnego na zawartość karotenoidów, cukrów rozpuszczalnych i związków fenolowych w marchwi. Roczniki AR w Poznaniu, CCCLXXXIII: 619-623.

SZWALEC A., MUNDAŁA P. 2012. Contents of $\mathrm{Cd}, \mathrm{Pb}, \mathrm{Zn}$ and $\mathrm{Cu}$ in root vegetables cultivated in Krakow City allotment gardens. Ochrona Środowiska i Zasobów Naturalnych 53: 31-40

TAMME T., REINIK M., ROASTO M., JUHKAM K., TENNO T., KIIS A. 2006. Nitrates and nitrites in vegetables and vegetablebased products and their intakes by the Estonian population. Food Additives \& Contaminants 23: 355-361.

WOJCIECHOWSKA R. 2005. Akumulacja azotanów a jakość produktów ogrodniczych. Wyd. Coperite, Kraków: 21-27.

WRZODAK A., ELKNER K. 2010. Jakość sensoryczna marchwi świeżej i przechowywanej z uprawy ekologicznej. Nowości Warzywnicze T50: 93-101.

WSZELACZYŃSKA E., POBEREŻNY J., KEUTGEN A. 2014. Effect of Genetic Conditions, Foliar Fertilisation with Magnesium and Storage on the Content of Nitrates (V) and (III) in the Storage Roots in Carrot. Ochrona Środowiska i Zasobów Naturalnych 25: 7-11.

ZALEWSKA-KORONA M., JABŁOŃSKA-RYŚ E., RADZKI W., GUSTAW W., SŁAWIŃSKA A., MICHALAK-MAJEWSKA M. 2015. Usefulness of selected broccoli varieties for freezing. Polish Journal of Natural Sciences 30: 91-97. 